\title{
Implementing the Resource Sharing Innovation Model to Sustainably Address the High Unemployment Rate
}

\author{
Bambang Dwi Suseno, Furtasan Ali Yusuf ${ }^{2}$, Syamsul Hidayat', and Dewi \\ Surani ${ }^{2}$ \\ ${ }^{1}$ Fakultas Ekonomi dan Bisnis, University of Bina Bangsa, Banten, Indonesia \\ ${ }^{2}$ Fakultas Keguruan dan IImu Pendidikan, University of Bina Bangsa, Banten, Indonesia
}

ORCID:

Bambang Dwi Suseno: http://orcid.org/0000-0001-8196-6146

Corresponding Author:

Syamsul Hidayat

mastersyah@gmail.com

Published: 22 March 2021

Publishing services provided by

Knowledge E

(c) Bambang Dwi Suseno

et al. This article is distributed

under the terms of the

Commons Attribution License,

which permits unrestricted use and redistribution provided that the original author and source are credited.

Selection and Peer-review under the responsibility of the ICOEN Conference Committee.

\section{Abstract}

There is a paradoxical condition in which Banten Province is an area with an abundance of manufacturing companies, but has a high unemployment rate. So it is important to carry out research to provide innovative and sustainable policy mix recommendations for local governments. This study aims to analyze (1) the relationship between training revolving funds and the competence of vocational school graduates, (2) the relationship between training revolving funds and the skill development center, (3) the relationship between the competence of vocational school graduates and the skill development center, (4) the relationship between the competence of vocational education graduates and resource sharing innovation, (5) the relationship between resource sharing innovation and skill development centers, (6) resource sharing innovation with industrial human competitiveness, and (7) the effect of development center skills on industrial human competitiveness. This study used Research and Development (R\&D) methods with participants from selected companies who were willing to accept vocational graduates as apprentices. After the data were collected, they were processed using the IBM AMOS 2.2 application. The findings were confirmed through triangulation with the person in charge of apprenticeships at the seven participating companies. The willingness to do resource sharing innovation (RSI) had an effect on the competitiveness of industrial people. Based on these results, it can be concluded that RSI, offered as a novelty, can increase the competitiveness of industrial people. These results can be used to overcome the high unemployment rate through RSI from companies in the region providing business convenience incentives.

Keywords: Resource Sharing Innovation, Unemployment, Sustainability

\section{Introduction}

According to BPS data, the number of working population in Banten Province increased from 5.62 million people in 2018 to 5.68 million people in 2019. With the largest main employment structure covering trade amounting to 23.88 percent or 1.36 million people, 
processing industry by 19.97 percent or 1.13 million people, agriculture, mining and quarrying by 12.72 percent or 722,120 people[1].

Meanwhile, the unemployment rate in Banten in the August 2019 period was the highest in Indonesia, namely $8.11 \%$ while the national unemployment rate was $5.28 \%$. The ability of Banten Province in preparing employment opportunities is conspicuous compared to other provinces with the fact that the unemployment rate is $8.11 \%$ [2]. Although the Banten Provincial Government has made efforts to reduce the unemployment rate, the reality is not yet encouraging. Facts show that in 2017 Banten was ranked 2nd nationally. The following year 2018 rose to rank 1. Furthermore, in 2019 it returned to rank 1 even though it decreased relatively by $0.14 \%$ from $8.25 \%$ to $8.11 \%$ [1].

Based on the potential for employment, it can be examined through three industrial areas, namely Serang Regency, Cilegon City and Tangerang Regency as the basis for manufacturing companies, which turns out to be paradoxically the highest contributor to unemployment in Banten Province. Serang Regency became the highest contributor with $10.65 \%$, followed by the second highest, Cilegon Regency with $9.68 \%$ and Tangerang Regency 8.91\% [1]. In fact, if we look at districts / cities with high unemployment, for example, Serang Regency has 847 large companies, Tangerang Regency 3,858 units, and Cilegon City with 878 company units [3]. The purpose of this research is to find answers and formulation of innovative and appropriate policy models to overcome high unemployment in Banten Province.

The classical theory of labor which was pioneered by Pigou [4] explains that the labor market consists of the demand and supply of labor. The demand for labor which corresponds to the demands of the industrial needs is a derivative demand, which is obtained from the decreasing share of the marginal product of labor. Several previous studies on unemployment have been conducted by (Alghofari [5], Baeti [6], Budiani [7], Hadroj [8], Heriansyah, Nuraini, \& Kusuma [9], Imsar [10], Machin \& Manning [11], Santoso [12], Setiyawati \& Hamzah [13], Winardi [14], Yacoub [15].

\section{Methods and Equipment}

This research used Research and Development (R\&D) approach [17]. Respondents for apprentices at selected companies that are willing to accept apprentices from vocational graduates. After the data is collected, then had processed using IBM AMOS 2.2 software. The findings and tests then confirmed through triangulation to the person in charge of apprenticeship at the seven participating companies. 


\section{Results}

In this CFA model, it is conducted to test the indicators on each latent variable and the relationship between latent variables. Indicator testing is done by looking at the loading value of the indicator on the latent variables for both exogenous and endogenous variables. The results of standardized regression calculations show that the loading value is $>0.5$, it means that all indicators are valid as a measure of their latent variables. This CFA model also produces correlation values between latent variables, both exogenous and endogenous latent variables.

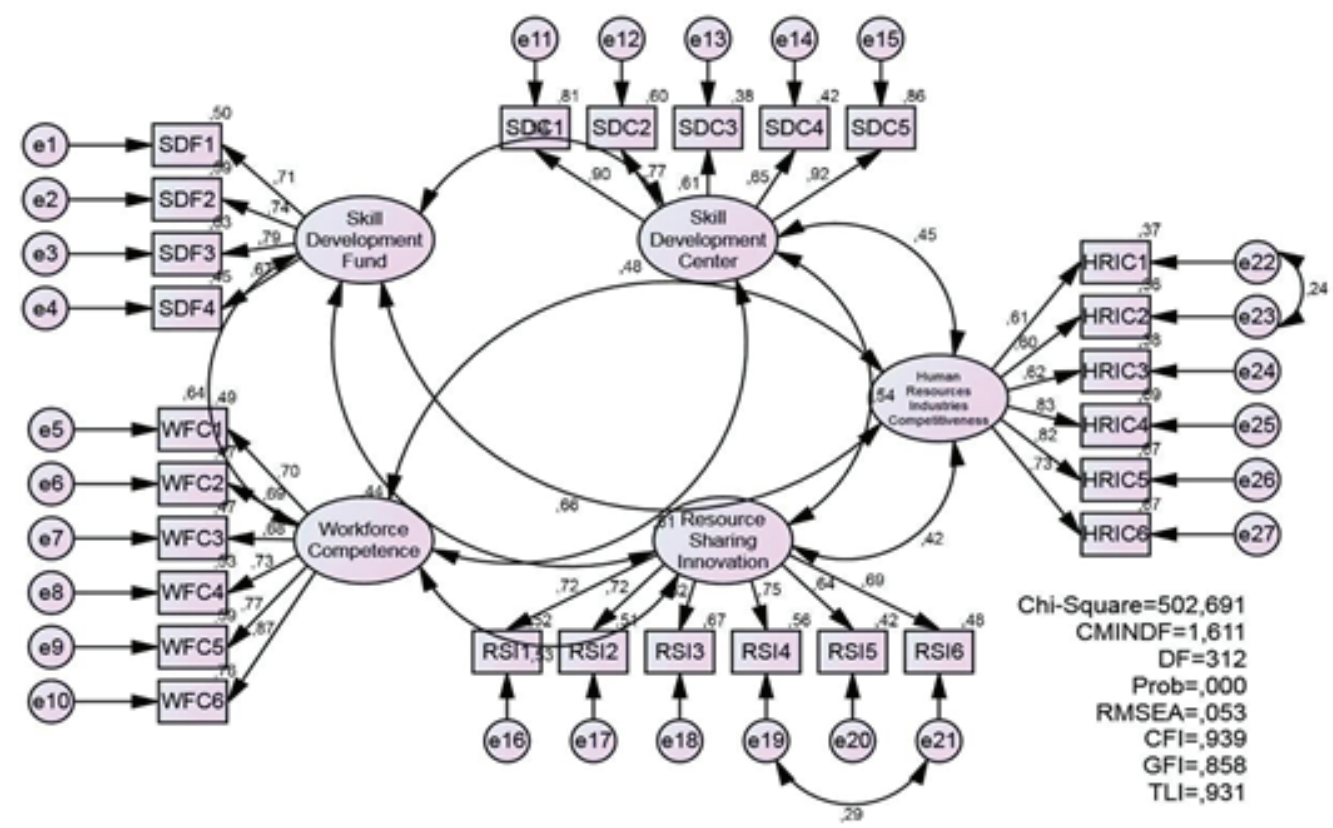

Figure 1: CFA Model

The results of the hypothesis test show that the estimated correlation value between the latent variables of the Skill Development Fund (training revolving fund), Skill Development Center, Resource Sharing Innovation, Workforce Competence (Competence of vocational school graduates), and Human Resources Industries Competitiveness each has a significant correlation value. This can be done by testing the structural model according to the hypothesis that has been developed.

\section{Discussion}

The results of testing the complete hypothesis through the following discussion:

First, the results of statistical testing on the estimated value of the effect of the Skill Development Fund on the Workforce Competence are 0.615 , the CR value is 7.075 


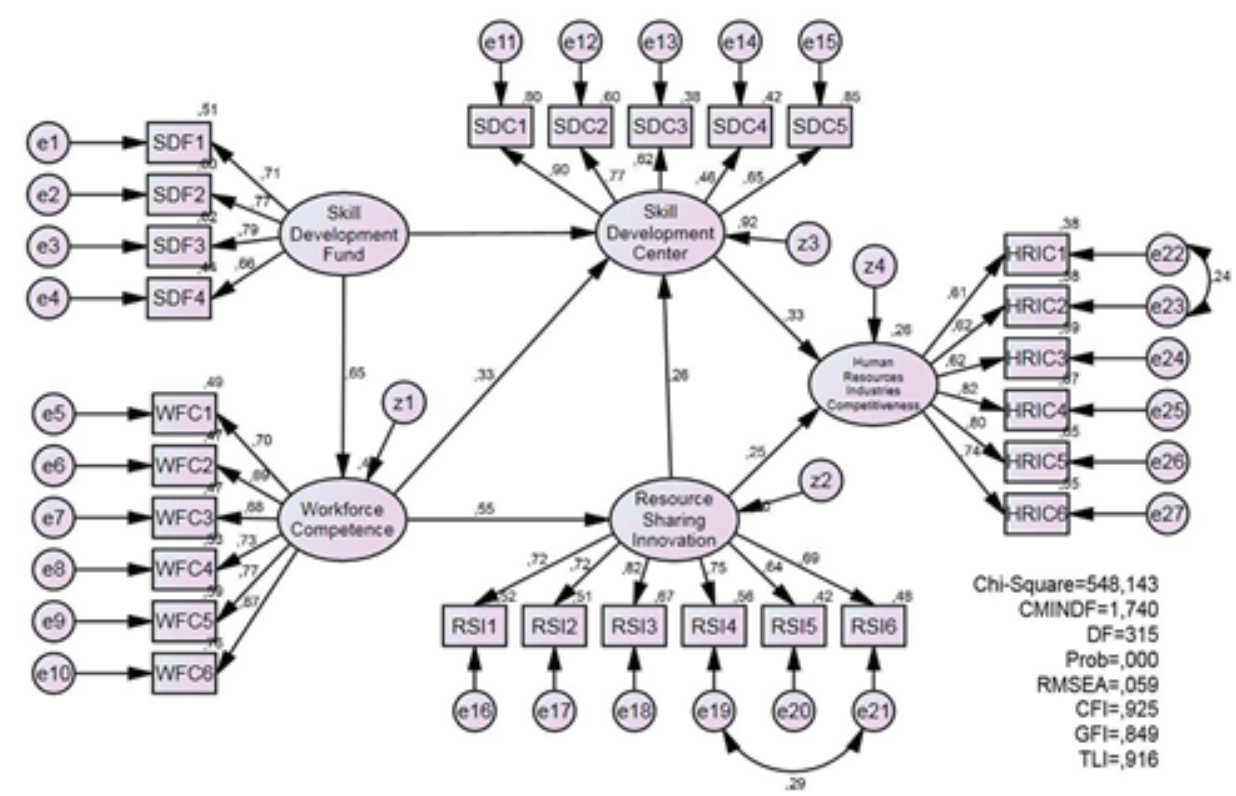

Figure 2: Full Structural Model

TABLE 1: Hypothesis Testing Results

\begin{tabular}{|c|c|c|c|c|c|c|}
\hline \multicolumn{2}{|c|}{ Influence path } & \multirow{2}{*}{$\begin{array}{c}\text { Estimate } \\
\text {,615 }\end{array}$} & \multirow{2}{*}{$\begin{array}{l}\text { S.E. } \\
, 087\end{array}$} & \multirow{2}{*}{$\begin{array}{l}\text { C.R. } \\
7,075\end{array}$} & \multirow{2}{*}{$\begin{array}{c}\mathrm{P} \\
* * *\end{array}$} & \multirow{2}{*}{$\begin{array}{c}\text { Result } \\
\text { Significant }\end{array}$} \\
\hline Workforce_Competence & Skill_Development_Fund & & & & & \\
\hline Resource_Sharing_Innovation & Workforce_Competence &, 570 & ,089 & 6,413 & $* * *$ & Significant \\
\hline Skill_Development_Center & Skill_Development_Fund & ,307 & 122 & 2,512 & ,012 & Significant \\
\hline Skill_Development_Center & Workforce_Competence & ,478 & 145 & 3,296 & $* * *$ & Significant \\
\hline Skill_Development_Center & Resource_Sharing_Innovation & ,370 & ,108 & 3,443 & $* * *$ & Significant \\
\hline Human_Resource_Industries_Competitiveness & Skill_Development_Center & ,230 & 061 & 3,766 & $* * *$ & Significant \\
\hline Human_Resource_Industries_Competitiveness & Resource_Sharing_Innovation & 247 & ,087 & 2,839 & ,005 & Significant \\
\hline
\end{tabular}

and the $p$-value is 0.000 . Based on these results, it can be concluded that the training revolving fund has a significant positive effect on the competence of vocational school graduates at the $5 \%$ significance level.

Second, the results of statistical testing on the estimated value of the effect of the Skill Development Fund on the Skill Development Center are 0.307, the CR value is 2.512 and the p-value is 0.012 . Based on these results, it can be concluded that the training revolving fund has a significant positive effect on the Skill Development Center at the $5 \%$ significance level.

Third, the results of statistical tests on the estimated value of the influence of the Workforce Competence on the Skill Development Center of 0.478 , the CR value of 3.296 and the p-value of 0.000 . Based on these results, it can be concluded that it is proven that the Competence of Vocational School Graduates has a significant positive effect on the Skill Development Center at the 5\% significance level. Fourth, the results of statistical tests on the estimated value of the influence of Workforce Competence on 
Resource Sharing Innovation of $0.570, C R$ value of 6.413 and $p$-value of 0.000 . Based on these results, it can be concluded that it is proven that the Competence of Vocational Education Graduates has a significant positive effect on Resource Sharing Innovation at the 5\% significance level. The average competency achievement of SMK graduates in Banten Province is still notencouraging.

Fifth, the results of statistical testing on the estimated value of the influence of Resource Sharing Innovation on the Skill Development Center are 0.370, the CR value is 3.443 and the p-value is 0.000 . Based on these results, it can be concluded that Resource Sharing Innovation has a significant positive effect on the Skill Development Center at the $5 \%$ significance level.

Sixth, the results of statistical testing on the estimated value of the influence of the Skill Development Center (SDC) on Human Resources Industries Competitiveness are 0.230 , the CR value is 3.776 and the p-value is 0.000 . Based on these results, it can be concluded that it is proven that the Skill Development Center has a significant positive effect on industrial human competitiveness at the $5 \%$ significance level. This evidence suggests that the Skill Development Center can act as a collaborative bridge.

Seventh, the results of statistical testing on the estimated value of the effect of Resource Sharing Innovation on Human Resources Industries Competitiveness are $0.247, \mathrm{CR}$ value is 2.839 and $p$-value is 0.005 . Based on these results, it can be concluded that it is proven that Resource Sharing Innovation (RSI) has a significant positive effect on Industrial Competitiveness at the $5 \%$ significance level. These results prove that openness to resource sharing will result in a real technology transfer process [14] from the manufacturing sector industry.

\section{Conclusion}

Based on these results, it can be concluded that it is proven that Resource Sharing Innovation offered as novelty can increase the competitiveness of industrial people. Theoretically and conceptually research broadens the theory and concepts in human resource management practices, especially related to human resource training and development as well as the concept of strategic management where the competitive advantage of the resource requirements must be consolidated. Furthermore, the managerial implications of the research results can provide a way out to overcome the high unemployment rate in an area through Resource Sharing Innovation from companies in the region by providing business convenience incentives. 


\section{Funding}

This work was supported by Kementerian Riset Dan Teknologi/Badan Riset Dan Inovasi Nasional (RISTEK/BRIN) under Grant No. 29/INS-1/PPK/E4/2020.

\section{Acknowledgement}

The authors would like to thank their colleague for their contribution and support to the research. They are also thankful to all the reviewers who gave their valuable inputs to the manuscript and helped in completing the paper.

\section{Conflict of Interest}

The authors have no conflict of interest to declare.

\section{References}

[1] BPS. (2019). Keadaan Ketenagakerjaan Banten Agustus 2019. Banten: BPS.

[2] DetikFinance2. (November, 2019). Pengangguran di Banten Tertinggi se-Indonesia, Ini Sebabnya. Retrieved on August 25 from https://finance.detik.com/beritaekonomi-bisnis/d-4772807/pengangguran-di-banten-tertinggi-se-indonesia-inisebabnya.

[3] Suseno, B. D. (2019). The Strength of Justified Knowledge Sharing on Good Manufacturing Practices: Empirical Evidence on Food Beverage Joint Venture Company of Japan - Indonesia. Quality - Access to Success, vol. 20, issue 170, pp. 130-135.

[4] Pigou, A. (1933). The Theory of Unemployment. Frank Cass And Company Limited. London.

[5] Alghofari, F. (2010). Analisis Tingkat Pengangguran di Indonesia Tahun 1980-2007. Universitas Diponegoro. Semarang.

[6] Baeti, N. (2013). Pengaruh Pengangguran, Pertumbuhan Ekonomi, Dan Pengeluaran Pemerintah Terhadap Pembangunan Manusia Kabupaten/Kota Di Provinsi Jawa Tengah Tahun 2007-2011. Economics Development Analysis Journal, vol. 2, issue 3, pp. 85-98.

[7] Budiani, N. W. (2005). Efektivitas Program Penanggulangan Pengangguran Karang Taruna "EKA TARUNA BHAKTI" Desa Sumerta Kelod Kecamatan Denpasar Timur 
Kota Denpasar. Ekonomi Dan Sosial INPUT, vol. 2, issue 1, pp. 49-57.

[8] Hadroj, A. (2016). Unemployment - Theoretical Overview. International Scientific Conference-ERAZ. Belgrade: ERAZ, pp. 564-571.

[9] Heriansyah, R. D., Nuraini, I. and Kusuma, H. (2018). Analisis Pengaruh Jumlah Industri Dan Indeks Pembangunan Manusia Terhadap Jumlah Penduduk Miskin Di Kabupaten/Kota Provinsi Banten Tahun 2012-2016. Jurnal Ilmu Ekonomi, vol. 2, issue 3, pp. 453-463.

[10] Imsar, I. (2018). Analisis Faktor-Faktor Yang Mempengaruhi Tingkat Pengangguran Terbuka Di Provinsi Lampung (Periode 1989-2016). Human Falah, vol. 5, issue 1, pp. 144-164.

[11] Machin, S. and Manning, A. (1999). Chapter 47 The Causes and Consequences of Long Term Unemployment in Europe. Handbook of Labor Economics, vol. 3, issue 3, pp. 3085-3139.

[12] Santoso, M. B. (2014). Kompetensi Lokal Dalam Menanggulangi Kemiskinan Di Daerah Industri. Share: Social Work Journal, vol. 4, issue 2, pp. 154-159.

[13] Setiyawati, A. and Hamzah, A. (2007). Analisis Pengaruh PAD, DAU, DAK, Dan Belanja Pembangunan Terhadap Pertumbuhan Ekonomi, Kemiskinan, Dan Pengangguran: Pendekatan Analisis Jalur. Jurnal Akuntansi Dan Keuangan Indonesia, vol. 4, issue 2, pp. 211-228.

[14] Suseno, B. D. and Dwiatmadja, C. (2016). Technology Transfer Motive Of Manager In Eastern Asia: Empirical Results From Manufacture Industry In Banten Province, Indonesia. Dipublikasikan pada Jurnal Problems and Perspectives in Management, vol. 14 , issue 2 , pp. 36-45.

[15] Siregar, H. (2017). Dampak Pembangunan Kawasan Industri Terhadap Output, Penyerapan Tenaga Kerja, Distribusi Pendapatan dan Kemiskinan Rumah Tangga di Provinsi Jawa Barat (Institut Pertanian Bogor). Institut Pertanian Bogor. Bogor, Jawa Barat.

[16] Yacoub, Y. T. P. (2012). Pengaruh Tingkat Pengangguran terhadap Tingkat Kemiskinan Kabupaten/Kota di Provinsi Kalimantan Barat. Jurnal EKSOS, vol. 8, issue 3, pp. 176-185.

[17] Gall, M. D., Gall, J. P. and Borg, W. R. (2003). Educational Research An Introduction ( $7^{\text {th }}$ ed.). Boston: Pearson Education Inc. 